\title{
AGE AND SEX COMPOSITION OF NEPAL SPOTLIGHTING BY PROVINCES: A TREND ANALYSIS (2001-2031)
}

Rita Devi Karki*

\section{ABSTRACT}

Age and sex structure of population of particular region is key determinants for development. The population of Nepal is in transition phase due to the decreasing trend of the birth and death rates; as a result, the situation of demographic windows of opportunity is started in the country. However, the demographic window of opportunity as human resources of Nepal is being magnetized and used by different foreign countries in the world. So to take advantage of economic growth, it needs to invest in the youth of the country with consideration of gender equality. This paper explores the working age population, dependency ratio, index of ageing and sex ratio by provinces which has not been studied yet in the country. The data for this study were drawn from National Report 2001 and 2011 censuses and calculated by using Microsoft Excel. The population was projected by using exponential growth function for 2031. The working age population is growing in Nepal in all provinces except province six. It will arrive at in $\mathbf{6 3 . 0}$ percent at national level and the highest $(77.3 \%)$ in province three by 2031 . The data seem to be interesting that the working age population of female is higher than male in all the years of the censuses. Although the ageing population is in the increasing trend, the overall dependency ratio is decreasing in almost all provinces. The problem of brain drain and issue of gender equality and equity in acceleration of nation's development are considerable population management matters in Nepal.

Keywords: Working age population, dependency ratio, sex ratio, exponential method, window of opportunity.

\section{INTRODUCTION}

Each population age structure presents different challenges. Population age structure has implications for national policy agendas and resource allocation (Population Reference Bureau, 2018) because the needs

* Ms. Karki is a Lecturer, Department of Population Studies, Ratna Rajya Laxmi Campus, Kathmandu, TU. 
and activities of population are different in various age groups and by sex. The structure of age and sex and its information is very important to analyze the social, economic and demographic aspects and make the plan on it present and future. Age and sex composition are the key determinants of fertility, mortality, migration and level of social and economic development. So the positive gender lens is essential to manage the population properly and achieve the development goals for nation's prosperity. Showing this situation, Adhikary (2014) mentioned that a society's age and sex structure has important implications for socio-economic and demographic development, as well as for labor force participation and gender relations. Ralf (1965) as cited in Bhende \& Kainkar (2000) stated, sex and age are very important because they are the visible, indisputable and convinient indicators of social status. He also reveals that the attitude of society towards children, the youths and elderly people are affected by age and sex distribution of population. The role in the family and society is associated with sex and age which is culturally determinded and varied in interculture and even in intraculture. For intance, it has happened that the situation is changed considerably and many women take to gainful employment though men have not taken to housekeeping in the large cities of developing countries as well. Shakya (2014) stated that Neplease society thinks that household chores and related activities are a woman's responsibility. The number of female is more than male in Nepal, but the males dominate in all socio-economic activities. It is an important issue for further study to identify the work burden of women and its impact in her life.

The age structures of different populations are usually compared in terms of three broad age groups which identify persons in the working age (15-64), children under the working age (0-14) and persons above the working age (65 and above) (Bhende \& Kainkar, 2000) however, the working age and old age population are defined differently in different countries. In Nepal, 0-14 age is taken as child dependent population, 15-59 age group is working age and 60 years and above is old age or old dependent population (Adhikary, 2014). The age structure of population affects a nation's key socio-economic issues. Countries with high percentage under age 15 need to invest more in schools, while countries with high percentage of older populations need to invest more in the health sector. The age structure can also be used to help predict potential political issues. It might be that the rapid growth of a young adult population is unable to get employment that can lead to unrest (The World Factbook, 2018). Hence, the economic and the social development of nation depend on the number of persons who are economically active, the quality of their works and regularity of their employment (Dhakal, 2014). So, the 'demography' is not density, it 
is considerable matter that how population dynamics unfold over the next decades, and whether they compound developmental challenges or help facilitate their resolution, depends on whether effective policies are put in place that are rights-based, evidence informed and gender-responsive. But on society as whole, as seen in the case of gender imbalance in some parts of the developing world (UNFPA, UNDESA, UN-HABITAT, IOM, 2013).

The working age population has been increasing in Nepal, while the proportion of the young age population has been declining. The relatively lower proportion of working age men to women is likely attributable to the fact that many men leave the country for work. The demographic dividend has begun in Nepal with subsequent change in the age structure of the population (UNFPA, 2017). However, demographic dividend is not autometically translated to the nation's economic development (Arayal, 2014). So the country has a 'window opportunity', for rapid economic growth, governments must implement economic policies that create jobs and economic growth if the right social and economic policies developed and investments made as South Korea and the other Asian Tigers was that, as they were making investments in health, education, and family planning, governments were also creating policies to attract foreign investment, promote the export of locally manufactured goods, and create a minimum wage to raise standards of living (Gribble \& Bremner, 2012).

The social and economic development affects population elements and vice versa. Since population is multi-sectoral and cross cutting issue and need to manage the population structure and distribution properly to contribute development of the country. Therefore, population policies should be designed keeping in mind future perspectives (Arayal, 2014) according to the dynamic nature of population. It is obvious that population is denominator of development. The population size, age and sex structure and spatial distribution are important components of a nation or particular geographical region for development. There is lack of study on age and sex composition of population and its characteristics considering the provincial level of Nepal. Hence, this study tries to analyze on population characteristics by sex namely working age population, dependent population, index of ageing and sex ratio at province level and national level based on in 2001 and 2011 censuses and it is also projected for 2031 .

\section{OBJECTIVE}

This study tries to analyze the age and sex structure of population of Nepal in general and it attempts to assess the working age population, dependency ratio, and index of ageing at national and provincial level 
drawing the data from 2001 and 2011 censuses with the projection of these compositions for 2031 in particular.

\section{METHODOLOGY}

The data were taken from National Report of 2001 and 2011 censuses which was published by Central Bureau Statistics office. Table number 10 (Population by five year age groups sex and sex ratio for regions and districts) of 2001 census and table number 16 (Population by 5 year age group) of 2011 census's data were used in this study. The essential data were calculated by using Microsoft Excel. Firstly the data were separated in different age groups by sex (0-14, 15-59 and 60 and above) and drawn the total number in national and districts level. The data were drawn by considering 75 districts for particular province. Because of limitation of available data, the whole part Nawalparasi district's population is included in province four and Rukum's population is incorporated in province five. After calculating the total number of population in different age group by sex in different provinces, the working age population, dependency ratio, child and old age dependency ratio, index of ageing and sex ratio were calculated for 2001 and 2011 censuses. By using the data of these censuses, growth rate was computed by applying exponential growth function and projected the population by age and sex for the year 2031 A. D. by provinces. Following methods and formulas were used to calculate the data in this study:

Table 1: Formula Used to Calculate the Age Composition of Population

\begin{tabular}{|l|c|}
\hline $\begin{array}{l}\text { Age Composition } \\
\text { of Population }\end{array}$ & \multicolumn{1}{c|}{ Formula } \\
\hline $\begin{array}{l}\text { Working age } \\
\text { population }\end{array}$ & $\frac{\text { Population aged } 15-59 \text { years }}{\text { Total Population }} \times 100$ \\
\hline $\begin{array}{l}\text { Age Dependency } \\
\text { ratio }\end{array}$ & $\frac{\text { Population aged } 0-14+60 \text { and above years }}{\text { Population aged } 15-59 \text { years }} \times 100$ \\
\hline $\begin{array}{l}\text { Child Dependency } \\
\text { Ratio }\end{array}$ & $\frac{\text { Population aged } 0-14 \text { years }}{\text { Population aged } 15-59 \text { years }} \times 100$ \\
\hline $\begin{array}{l}\text { Old Age } \\
\text { Dependency Ratio: }\end{array}$ & $\frac{\text { Population aged } 60 \text { and above years }}{\text { Population aged } 15-59 \text { years }} \times 100$ \\
\hline Index of Ageing & $\frac{\text { Population aged } 60 \text { and above years }}{\text { Population aged } 0-14 \text { years }} \times 100$ \\
\hline $\begin{array}{l}\text { Exponential Growth } \\
\text { Function }\end{array}$ & $\begin{array}{l}\text { Pt=Po.e } \text { r.t }[\text { Where, Pt }=\text { Population of the later year; Po } \\
=\text { Population of the earlier year; } \mathrm{t}=\text { Time interval; e }= \\
\text { Exponential form of natural logarithm (i.e., e=2.718)] }\end{array}$ \\
\hline
\end{tabular}




\section{RESULT AND DISCUSSION}

\section{Working Age as Bulged Population}

The proportion of population aged 15-59 years to the total population is called working age population. Generally the working age population is taken as 15-64 year (Bhende \& Kainkar, 2000) however; 15-59 years age group is taken as working age population in the context of Nepal (Adhikary, 2014). It is clear that working age population is important human resources for the country's development. It is great opportunity if working age population can translate in to the nation's economic development (Arayal, 2014) and create jobs and economic growth if the right social and economic policies developed and investments made as in South Korea and the other Asian Tigers (Gribble \& Bremner, 2012) and it is also challenges if large volume of young adults are unable to find employment can lead to unrest (The World Factbook, 2018) in the country.

At this moment in the history of Nepal, demographic transition is opening a unique window of opportunity for country's development. As life expectancy increases and fertility rates fall, the working-age population grows faster than the young dependent population (Amin, Bajrachary, \& Bongaarts, 2017). The data presents the same situation that the working age population is growing in Nepal and all provinces except six province (53.0\% in $2001-51.2 \%$ in 2031 ). It is an important opportunity to reap a demographic dividend in Nepal.

Table 2: Percent Distribution of Working Age Population (15-59), to the Total Population by Provinces in Nepal, 2001-2031

\begin{tabular}{|l|l|l|l|l|l|l|l|l|l|}
\hline \multirow{2}{*}{ Provinces } & \multicolumn{3}{|c|}{ 2001 } & \multicolumn{3}{c|}{ 2011 } & \multicolumn{3}{c|}{ 2031 (Projected) } \\
\cline { 2 - 10 } & Total & Male & Female & Total & Male & Female & Total & Male & Female \\
\hline One & 54.4 & 53.5 & 55.31 & 58.5 & 56.0 & 60.7 & 67.2 & 61.9 & 72.6 \\
\hline Two & 52.2 & 52.1 & 52.3 & 53.9 & 53.04 & 54.8 & 57.3 & 55.2 & 60.6 \\
\hline Three & 57.6 & 57.6 & 57.5 & 63.3 & 62.5 & 64.0 & 77.3 & 73.4 & 79.8 \\
\hline Four & 52.9 & 49.9 & 55.6 & 57.0 & 52.9 & 60.6 & 65.6 & 59.6 & 71.1 \\
\hline Five & 52.2 & 50.6 & 53.8 & 55.5 & 52.4 & 58.3 & 62.6 & 55.6 & 68.4 \\
\hline Six & 53.0 & 52.5 & 53.6 & 52.2 & 51.0 & 53.5 & 51.2 & 48.0 & 52.4 \\
\hline Seven & 51.5 & 50.4 & 52.6 & 52.9 & 50.6 & 55.0 & 56.2 & 51.6 & 59.6 \\
\hline Nepal & 54.1 & 53.3 & 55.01 & 57.0 & 55.0 & 58.8 & 63.0 & 59.6 & 67.6 \\
\hline
\end{tabular}

Source: National Report 2001 and 2011

Province three is with the highest share of working population in the two census years 2001 and 2011 and it is projected 77 percent in 2031 . 
It is clear that the movement of people is mainly centered in capital of Nepal, Kathmandu including Lalitpur and Bhakatpur and some developed districts for their employment opportunities and better living arrangement. The data seem to be interesting that the working age population of female is higher than male in all the years of the censuses including projected year 2031 and in all provinces except province three in 2001 census. It is also the result of massive male migration overseas (Arayal, 2014). The data in working age population by sex does not seem matched with the practical representation of female in different socio-economic and political sectors because generally male are dominant in every sectors including the policy and decision makes bodies in Nepal. It is serious issue for the development to use of human resources. It needs to invest not only in female's education and health but also in the leaderships in different sectors and meaningful participation and decision making role which is very important for nation's prosperity.

\section{Dynamics of Age Dependency Ratios}

Age dependency ratio is the key for economic growth to determine high dependency ratios; it means more investment of resources in taking care of dependents. It is clear that the demographic transition and its consequent age-structural changes leading to the rising ratio of the working age population (15-59) and the declining ratio of the child population (0-14) (Bhagat, 2014) and population 60 years and increasing in proportion of population 60 years and above. This further implies a consequent increase of life expectancy at birth and decline in death rates for each year has been decreasing (Arayal, 2014) in Nepal.

Table 3: Variation in Age Dependency Ratio in Nepal by Provinces, 20012031

\begin{tabular}{|l|l|l|l|l|l|l|l|l|l|}
\hline \multirow{2}{*}{ Provinces } & \multicolumn{3}{|c|}{ 2001 } & \multicolumn{3}{c|}{ 2011 } & \multicolumn{3}{c|}{ 2031 (Projected) } \\
\cline { 2 - 10 } & Total & Male & Female & Total & Male & Female & Total & Male & Female \\
\hline One & 83.9 & 87.1 & 80.8 & 71.1 & 78.4 & 64.9 & 56.5 & 69.6 & 46.2 \\
\hline Two & 91.6 & 92.0 & 91.2 & 85.4 & 88.6 & 82.3 & 77.3 & 85.4 & 68.7 \\
\hline Three & 73.8 & 73.6 & 73.9 & 58.1 & 60.0 & 56.2 & 38.1 & 41.5 & 34.7 \\
\hline Four & 89.2 & 100.6 & 80.0 & 75.3 & 89.2 & 65.1 & 59.7 & 76.4 & 48.8 \\
\hline Five & 91.5 & 97.5 & 85.9 & 80.2 & 90.9 & 71.5 & 64.6 & 83.9 & 53.4 \\
\hline Six & 88.6 & 90.5 & 86.7 & 91.4 & 96.2 & 87.0 & 101.9 & 112.8 & 93.8 \\
\hline Seven & 94.0 & 98.2 & 90.1 & 88.9 & 97.6 & 81.7 & 83.0 & 98.0 & 71.9 \\
\hline Nepal & 84.7 & 87.7 & 81.8 & 75.6 & 81.8 & 70.1 & 64.1 & 73.9 & 54.7 \\
\hline
\end{tabular}

Source: National Report 2001 and 2011 
The data explain the same situation that the dependency ratio is in decreasing trend where 84.7 was in 2001 and it is decreased in 75.6 in 2011 census. It will be decrease in 64.1 by 2031 . The low dependency ratio is found in province three in all census including projected year 2031 and it will be high in province six by 2031 (101.9) from 2011 census (91.4) (Table 3 ). It may the result of high volume of outgoing working age population of that region. There is a notable variation in dependency ratio by sex. Female dependency ratio is less likely to compare in all most all provinces of Nepal. So, it needs to be attention to make the appropriate plan and action with addressing gender disaggregated data and its future management of population in time.

\section{Child Dependency Ratio}

Analysis of dynamics in child dependency ratio (0-14 years to 15-59 years) presented in Table 4. Population Reference Bureau (2018) highlights the situation that child dependency face challenges in investing sufficient resources in the development of young people's human capital. If such investments are made, these countries have an opportunity to reap the economic growth benefits of a larger, better educated working-age population.

Table 4: Dynamics of Child Dependency Ratio in Nepal by Provinces, 2001-2031

\begin{tabular}{|l|l|l|l|l|l|l|l|l|l|}
\hline & \multicolumn{3}{|c|}{$\mathbf{2 0 0 1}$} & \multicolumn{3}{c|}{ 2011 } & \multicolumn{3}{|c|}{ 2031 (Projected) } \\
\cline { 2 - 10 } Provinces & Total & Male & Female & Total & Male & Female & Total & Male & Female \\
\hline One & 71.6 & 74.3 & 69.0 & 56.2 & 62.2 & 51.2 & 34.5 & 43.5 & 28.9 \\
\hline Two & 80.0 & 80.5 & 79.5 & 71.5 & 73.9 & 69.12 & 57.4 & 61.7 & 52.2 \\
\hline Three & 61.9 & 62.0 & 61.8 & 45.8 & 48.0 & 43.8 & 25.0 & 28.5 & 21.7 \\
\hline Four & 73.7 & 83.4 & 65.9 & 57.2 & 68.6 & 48.7 & 34.7 & 46.9 & 26.8 \\
\hline Five & 79.6 & 84.5 & 75.0 & 66.2 & 75.2 & 58.9 & 45.3 & 60.3 & 36.4 \\
\hline Six & 80.2 & 81.7 & 78.8 & 79.5 & 83.9 & 75.5 & 78.0 & 89.1 & 69.7 \\
\hline Seven & 82.8 & 86.9 & 79.0 & 74.7 & 83.3 & 67.4 & 59.9 & 75.3 & 49.0 \\
\hline Nepal & 72.7 & 75.4 & 70.1 & 61.3 & 31.2 & 30.0 & 43.6 & 51.4 & 36.4 \\
\hline
\end{tabular}

Source: National Report 2001 and 2011

The child dependency ratio is significantly decreasing in Nepal. It was 72.7 and 61.3 in 2001, 2011 censuses respectively and it will be 43.6 by 2031 . It may be the result of decreasing trend of fertility and child mortality. There is low child dependency ratio in the province three (61.9 in 2001, 45.8 in 2011, and 25.0 in 2031) and province one (71.6 in 2001, 56.2 in 2011 , and 43.5 in 2031) to compare with other provinces in all census 
years. Similarly, provinces no. two, six and seven have the highest child dependency ratio in comparison to other provinces.

Female child dependency ratio is low in all provinces and all census year to compare with male. It is because of heavy working age male migrated population to abroad. The result is consistent with the findings Central Bureau of Statistics (2014) where the lowest sex ratio was found in the age group 20- 34 years age. Similarly, Khatiwada (2014) also showed that there were about 88 percent male and 12 percent female were migrated to abroad and more than three fourth $(77.7 \%)$ male were $15-34$ years.

The child dependency ratio is in slightly increasing trend in province number six. It will be about 90 in 2031 from 84 of 2011 census. The provinces two, five, six, and seven have high child dependency ratio than national figure in 2011 census (61.3) and 2031 (43.6) although it seems drastic decreasing trend from 2001 to 2031 in National level. Moreover, it is only meaningful when the working age population should be employed and economically able to rearing and caring for dependent population.

\section{Old Age Dependency Ratio}

Ratio of old age population, i.e. 60 and above years to the working age population (15-59 years age) is called old age dependency ratio. The data show the old dependency ratio is in increasing trend because of increasing life expectancy at birth and decreasing of death at each age of population; conversely child dependency ratio started to decrease from 2001 due to the decrease in child mortality and fertility (Adhikary, 2014). It was 12.0 in 2001, 14.3 in 2011, and will be 20.5 in 2031 at national level. The old age dependency ratio of female is slightly higher in the province three in all census years than male and also in province six and seven in 2031.

Table 5: Dynamics of old Age Dependency Ratio in Nepal by Provinces, 2001-2031

\begin{tabular}{|l|l|l|l|l|l|l|l|l|l|}
\hline \multirow{2}{*}{ Provinces } & \multicolumn{3}{|c|}{ 2001 } & \multicolumn{3}{c|}{ 2011 } & \multicolumn{3}{c|}{ 2031 (Projection) } \\
\cline { 2 - 10 } & Total & Male & Female & Total & Male & Female & Total & Male & Female \\
\hline One & 12.3 & 12.7 & 11.8 & 14.8 & 16.2 & 13.7 & 21.7 & 26.2 & 18.1 \\
\hline Two & 11.6 & 11.5 & 11.8 & 13.9 & 14.7 & 13.2 & 20.0 & 23.7 & 16.4 \\
\hline Three & 11.9 & 11.5 & 12.2 & 12.2 & 12.0 & 12.5 & 13.0 & 13.0 & 13.0 \\
\hline Four & 15.5 & 17.2 & 14.1 & 18.1 & 20.5 & 16.4 & 25.0 & 29.5 & 22.1 \\
\hline Five & 11.9 & 13.0 & 10.9 & 14.0 & 15.8 & 12.6 & 19.3 & 23.5 & 16.7 \\
\hline Six & 8.4 & 8.8 & 7.9 & 11.9 & 12.2 & 11.5 & 23.9 & 23.7 & 24.1 \\
\hline Seven & 11.2 & 11.3 & 11.2 & 14.3 & 14.3 & 14.2 & 23.1 & 22.7 & 23.0 \\
\hline Nepal & 12.0 & 12.3 & 11.7 & 14.3 & 15.1 & 13.6 & 20.5 & 22.9 & 18.3 \\
\hline
\end{tabular}

Source: National Report 2001 and 2011 
Nepal has great window of opportunity to gain economic growth by using human resources and challenging to manage growing senior population for their well living arrangement. The support of family members or pension is important at the time of old age. But the high mobility and migration of people and scatter of family members and lacking well being provision for senior citizens by state is great challenging, specially at the time of mentally and physically inactive period of life in too old age. It is the result of improving in women's health condition and biological factors because generally women showed a longer life expectancy than male in almost every human society in the last decade of the $20^{\text {th }}$ century (Scientific American, 2018).

\section{Dynamics in Index of Population Ageing}

Index of ageing is the ratio of the number of persons aged 60 years and over to the number of under 15 years old. Population ageing is poised to become one of the most significant social transformations of the twentyfirst century. The older population of the developing regions is growing much faster than in the developed regions (United Nation, n. d.; and United Nations, Department of Economic and Social Affairs, Population Division, 2017). The index of ageing is affected by the level of fertility and expectancy of life of the people. If the fertility is low in the country, the below 15 children population is also low and increase the old population. In the same way, the index of ageing is increasing in Nepal.

Table 6: Distribution of Population by Index of Ageing in Nepal, by Provinces, 2001-2031

\begin{tabular}{|l|l|l|l|l|l|l|l|l|l|}
\hline \multirow{2}{*}{ Provinces } & \multicolumn{3}{|c|}{ 2001 } & \multicolumn{3}{c|}{ 2011 } & \multicolumn{3}{c|}{ 2031 (Projection) } \\
\cline { 2 - 10 } & Total & Male & Female & Total & Male & Female & Total & Male & Female \\
\hline One & 17.1 & 17.1 & 17.1 & 26.4 & 26.0 & 26.7 & 62.3 & 60.2 & 64.4 \\
\hline Two & 14.5 & 14.3 & 14.8 & 19.5 & 19.8 & 19.1 & 34.8 & 38.4 & 31.5 \\
\hline Three & 19.2 & 18.6 & 19.7 & 26.7 & 25.1 & 28.5 & 52.0 & 45.7 & 59.8 \\
\hline Four & 21.0 & 20.7 & 21.4 & 31.7 & 29.9 & 33.6 & 72.0 & 62.7 & 82.5 \\
\hline Five & 15.0 & 15.3 & 14.6 & 21.2 & 21.0 & 21.4 & 42.7 & 39.0 & 46.7 \\
\hline Six & 10.4 & 10.8 & 10.1 & 14.9 & 14.6 & 15.2 & 30.6 & 26.6 & 35.3 \\
\hline Seven & 13.6 & 13.0 & 14.1 & 19.1 & 17.2 & 21.1 & 38.5 & 30.1 & 46.9 \\
\hline Nepal & 12.0 & 12.3 & 11.7 & 23.3 & 22.6 & 24.03 & 46.9 & 43.7 & 50.3 \\
\hline
\end{tabular}

Source: National Report 2001 and 2011

It is about double from 2001 (12.0) census to 2011(23.3) and it will be about 47 by 2031. It means the population is going towards ageing. 
It is the serious concerns of demographic and developmental agenda. The three and four provinces has high index of ageing where 19.2 and 21.0 respectively in 2001 census than others provinces. The growing of index of ageing is faster in one, three and four province than others provinces where, in 2011 and 2031, the index of ageing on the province one 26.4 and 62.3, 26.7 and 52.2 in three and 31.7 and 72.0 in four in that order.

It will be more than 30 index of ageing in all provinces by 2031 . The ageing number of female will be much more growing than male in all provinces except two in 2031. It is the result of improving in health condition of female in Nepal. The improving condition of people's socio-economic development and access of health facilities are generally determinant factors of increasing the life expectancy of people and to reduce in level of fertility. It is also the symbol of number of older people growing faster than the number of people in all younger age group.

\section{CONCLUSION}

There is interrelationship between demographic outcomes namely size, age and sex structure and spatial distribution of population and socioeconomic development. The long term vision is important for sustainable development. The changing population dynamics issue plays a key role in multi sectors of development. Nepal has great chance to have demographic window opportunity to reap the economic growth. But it is great challenge to invest in education to train the young workers and create the productive work opportunities. Likewise, it is essential to address the medical and long term care needs and well being for growing number and proportion of older persons in the population. This study has drawn on age and sex structure of population in working age population and others dependent population for the next 20 years (2011-2031) which is an important and notable data to make appropriate policy and their effective implementation. The clear picture of available human resources by province level by sex and can make a grand plan to manage and utilization of labor force with gender lenses. The data show high working age population of female and it should be recognize as female are active agents of change equally as male not only beneficiaries. It must act quickly to increase women's economic participation. Similarly, it needs to control the international labor migration by providing the gainful employment for all available labor force in the country to achieve the national prosperity. Hence, it should be focus on more investment in need base practical education to utilize the resources for a young population for rapid economic growth. 


\section{REFERENCES}

Adhikary, U. P. (2014). Age sex composition. Population Monograph of Nepal (Vol. I, Population Dynamics, pp. 39-65). Kathmandu: Central Bureau of Statistics.

Amin, S., Bajrachary, A., \& Bongaarts, J. (2017). Demographic changes of Nepal: Trends and policy. Kathmandu: Planning Commission, Government of Nepal.

Arayal, R. H. (2014). Population policy in the context of changing demographic picture of Nepal. In Population Monograph of Nepal (Vol. II, Social Demography, pp. 377-398). Kathmandu: Central Bureau of Statistics.

Bhagat, R. B. (2014). The opportunities and challenges of demographic dividend in India. Jharkhand Journal of Development and Management Studies , 12 (4), 6099-6113.

Bhende, A. A., \& Kainkar, T. (2000). Principles of population studies (13 th ed.). Mumbay: Himalayan Publishing House.

Central Bureau of Statistics. (2014). Executive summary. Population monograph of Nepal (Vol. I, Population Dynamics). Kathmandu:Author.

Dhakal, B. (2014). An analytical study on present status of age-sex structure of Nepal. Asia Pacific Journal of Education, Arts and Sciences , 1 (3), 20-26. Retrieved from http://apjeas.apjmr.com/wp-content/ uploads/2014/07/APJEAS-2014-1-043.pdf.

Gribble, J., \& Bremner, J. (2012). The challenge of attaining. Washington, DC: Population Reference Bureau Retrieved from https://assets. prb.org/pdf12/demographic-dividend.pdf

Khatiwada, P. P. (2014). International migration and citizenship in Nepal. Population Monograph of Nepal (Vol. I, Population Dynamics, pp. 211-237). Kathmandu: Author.

Population Reference Bureau . (2018). World population data sheet. Washington, D.C.: Population Reference Bureau. Retrieved from https://www.prb.org/wp-content/uploads/2018/08/2018_WPDS.pdf

Scientific American. (2018). Why is life expectancy longer for women than it is for men? Retrieved Oct. 2018, from Scientific Amirican, a division of springer nature America, inc.: https://www.scientificamerican. com/article/why-is-life-expectancy-lo/ 
Shakya, K. (2014). Changing gender status:Achievements and challenges. Population Monograph of Nepal (Vol. II, pp. 221-271). Kathmandu:Author.

The World Factbook. (2018). Nepal age structure. Index mundi. Retrieved from https://www.indexmundi.com/nepal/age_structure.html.

UNFPA, UNDESA, UN-HABITAT, IOM. (2013). Population dynamics in the post-2015, development agenda: Report of the global thematic. UNFPA, UNDESA, UN-HABITAT and IOM.

United Nation. (n. d.). Ageing. Retrieved Oct. 2018, from http://www. un.org/en/sections/issues-depth/ageing/

United Nations Population Fund, (2017). Population situation analysis of Nepal. Kathmandu: Author.

United Nations; Department of Economic and Social Affairs; Population Division. (2017). World Population Ageing: Highlights. New York: Retrieved from http://www.un.org/en/development/desa/ population/publications/pdf/ageing/WPA2017_Highlights.pdf 